\title{
Measured by the oxygen uptake in the field, the work of refuse collectors is particularly hard work: Are the limit values for physical endurance workload too low?
}

\author{
Alexandra M. Preisser ${ }^{1} \cdot$ Linfei Zhou $^{1} \cdot$ Marcial Velasco Garrido $^{1} \cdot$ Volker Harth $^{1}$
}

Received: 9 December 2014 / Accepted: 3 June 2015 / Published online: 19 June 2015

(C) The Author(s) 2015. This article is published with open access at Springerlink.com

\begin{abstract}
Purpose Collecting waste is regarded as a benchmark for "particularly heavy" work. This study aims to determine and compare the workload of refuse workers in the field. We examined heart rate (HR) and oxygen uptake as parameters of workload during their daily work.

Methods Sixty-five refuse collectors from three taskspecific groups (residual and organic waste collection, and street sweeping) of the municipal sanitation department in Hamburg, Germany, were included. Performance was determined by cardiopulmonary exercise testing (CPX) under laboratory conditions. Additionally, the oxygen uptake $\left(\mathrm{VO}_{2}\right)$ and HR under field conditions (1-h morning shift) were recorded with a portable spiroergometry system and a pulse belt.

Results There was a substantial correlation of both absolute $\mathrm{HR}$ and $\mathrm{VO}_{2}$ during $\mathrm{CPX}\left[\mathrm{HR} / \mathrm{VO}_{2} R 0.89\right.$ (SD 0.07)] as well as during field measurement $[R 0.78(0.19)]$. Compared to reference limits for heavy work, $44 \%$ of the total sample had shift values above $30 \%$ heart rate reserve $\left(\mathrm{HR}_{\mathrm{R}}\right) ; 34 \%$ of the individuals had mean $\mathrm{HR}$ during work $\left(\mathrm{HR}_{\mathrm{sh}}\right)$ values that were above the HR corresponding to $30 \%$ of individual maximum oxygen uptake $\left(\mathrm{VO}_{2, \max }\right)$. All individuals had a mean oxygen uptake $\left(\mathrm{VO}_{2,1 \mathrm{~h}}\right)$ above $30 \%$ of $\mathrm{VO}_{2, \max }$.
\end{abstract}

Alexandra M. Preisser and Linfei Zhou are equally contributing first authors.

Alexandra M. Preisser

a.preisser@uke.de

1 Institute for Occupational and Maritime Medicine (ZfAM), University Medical Center Hamburg-Eppendorf, Seewartenstrasse 10, 20459 Hamburg, Germany
Conclusion $\mathrm{HR}$ as well as the measurement of $\mathrm{VO}_{2}$ can be valuable tools for investigating physiological workload, not only under laboratory conditions but also under normal working conditions in the field. Both in terms of absolute and relative $\mathrm{HR}$ and oxygen consumption, employment as a refuse collector should be classified in the upper range of defined heavy work. The limit of heavy work at about $33 \%$ of the individual maximum load at continuous work should be reviewed.

Keywords Oxygen uptake - Physically heavy work · Mobile spiroergometry $\cdot$ Relative heart rate $\cdot$ Waste collectors · Endurance work

\section{Introduction}

The organized collecting of waste is essential for a functioning community; however, there is no explicit job qualification connected with, and the work of garbage collectors receives little scientific attention. Collecting waste is described as physically demanding work and as being the cause of various physical disorders with respiratory, gastrointestinal, and musculoskeletal symptoms (Kuijer and Frings-Dresen 2004; Kuijer et al. 2010). This work is regarded as a benchmark for "particularly heavy" work. The definition of "heavy work" is based so far only on the assumption that the endurance limit is $30 \%$ respectively $33 \%$ of the maximum load capacity, taking into account load peaks, manual work, and harmful temperatures (Ilmarinen et al. 1991; Rutenfranz et al. 1976). The determination of an "upper limit" is essential for defining the "reasonableness" of a work-in the sense of the absence of excessive risks to health. There are presently also no indications, showing how the physical performance is with this 
heavy work with increasing age. An assessment is required in order to meet the challenges of demographic change in industrialized countries. Only few studies have investigated in detail the refuse collectors in different countries with different tasks. Up to now, the heart rate (HR) is used as an indirect indicator of the physiological workload, for example in the Netherlands (Kemper et al. 1990), Japan (Tsujimura et al. 2012), and Brazil (Anjos et al. 2007). The oxygen uptake $\left(\mathrm{VO}_{2}\right)$, as a direct measure of the metabolic processes, however, was mostly estimated via HR in these groups. So far, the $\mathrm{VO}_{2}$ of refuse collectors was determined only once by means of simulation in the laboratory (Kemper et al. 1990; Frings-Dresen et al. 1995). The relation between $\mathrm{HR}$ and $\mathrm{VO}_{2}$ has not yet been specified under field conditions. This may be due to the fact that the measurement of oxygen uptake with a breathing mask for outdoor work in this occupation group is technically particularly challenging. In our view, however, the conclusion of HR on $\mathrm{VO}_{2, \max }$ requires a review. To our knowledge, there are no recent studies with refuse collectors, who were investigated during their daily work with portable spiroergometry to determine the real oxygen uptake.

This paper is based on a study about the physiological workload of 65 employees from three task-specific groups [residual waste collection (RWC), organic waste collection (OWC), and street cleaning (SC)] of a municipal sanitation department in Germany. Our aim was to categorize the respective workload of these professions under real working conditions as a contribution to the development of a classification of workload in occupational health research. To evaluate the methods in the field of measurement, we also conducted comparisons of the methods of workload measurement. For this purpose, HR and oxygen uptake were determined in field measurements. For comparison, we measured the oxygen uptake by a stationary cycle cardiopulmonary exercise test (CPX).

\section{Methods}

The study group consisted of 65 subjects (62 males and 3 females), aged between 25 and 60, all employees in the municipal sanitation department in Hamburg, Germany. All participants volunteered and were granted compensatory time off by the employer. Before the start of the investigations, there was no selection of participants. The anthropometric characteristics of the subjects (Table 1) are representative in age and sex of the 1544 employees [46.5 (SD 8.6) years; $98 \%$ male) working in refuse collecting in this sanitation department. The examined employees were subdivided by their occupational tasks into three groups: RWC $(n=35)$, OWC (12), and SC (18). These jobs are mainly performed by male employees, although there are a few females in street sweeping in Hamburg. There were three women in the last group. The Declaration of Helsinki has been adequately addressed, and written informed consent was obtained from all participants. The study was approved by the Ethics Committee of the Hamburg Medical Association (register number PV4524).

Elements of investigation were specific questioning and physical examination (regarding occupation, symptoms, and disorders according to body functions). Furthermore, spirometry, body plethysmography (MasterScreen ${ }^{\mathrm{TM}}$ Body by JAEGER ${ }^{\mathrm{TM}}$ /CareFusion, Hoechberg, Germany), and CPX were performed with 61 subjects. Four persons were excluded due to cardiorespiratory risk factors.

Table 1 Characteristics of study participants

\begin{tabular}{|c|c|c|c|c|c|c|c|c|c|c|}
\hline & \multirow[t]{2}{*}{$N$} & \multirow[t]{2}{*}{ Female } & \multicolumn{2}{|c|}{ Age (years) } & \multicolumn{2}{|c|}{ Height (m) } & \multicolumn{2}{|c|}{ Weight (kg) } & \multicolumn{2}{|c|}{ BMI $\left(\mathrm{kg} / \mathrm{m}^{2}\right)$} \\
\hline & & & Mean & SD & Mean & SD & Mean & SD & Mean & SD \\
\hline All & 65 & 3 & 45.6 & 8.3 & 177.7 & 7.6 & 89.7 & 14.7 & 28.3 & 3.8 \\
\hline Male & 62 & & 45.5 & 8.4 & $177.0^{\mathrm{a}}$ & 8.3 & $88.7^{\mathrm{a}}$ & 15.3 & 28.2 & 3.9 \\
\hline Female & 3 & 3 & 43.1 & 11.5 & 162.0 & 9.6 & 65.7 & 7.4 & 25.2 & 4.3 \\
\hline RWC & 35 & - & $47.3^{\mathrm{b}}$ & 7.0 & 179.1 & 7.4 & 92.5 & 15.5 & 28.8 & 4.0 \\
\hline OWC & 12 & - & 46.7 & 8.3 & 177.8 & 5.3 & 94.3 & 12.8 & 30.0 & 4.0 \\
\hline $\mathrm{SC}$ & 18 & 3 & 41.6 & 9.7 & 175.0 & 9.0 & $81.2^{\mathrm{b}, \mathrm{c}}$ & 11.1 & $26.5^{b, c}$ & 2.8 \\
\hline $\mathrm{All}_{\text {field }}$ & 13 & 2 & 49.7 & 6.7 & 174.8 & 9.3 & 87.1 & 15.9 & 28.3 & 4.0 \\
\hline $\mathrm{RWC}_{\text {field }}$ & 5 & - & 51.1 & 4.0 & 178.6 & 11.5 & 88.6 & 12.5 & 27.6 & 1.2 \\
\hline OWC $_{\text {field }}$ & 3 & - & 50.4 & 6.3 & 175.7 & 3.8 & 103.0 & 14.5 & $33.4^{\mathrm{d}}$ & 4.9 \\
\hline $\mathrm{SC}_{\text {field }}$ & 5 & 2 & 47.8 & 9.6 & 170.6 & 9.0 & $76.0^{\mathrm{e}}$ & 12.3 & 26.0 & 2.8 \\
\hline
\end{tabular}

$S D$ Standard deviation, $B M I$ body mass index, $R W C$ residual waste collectors, $O W C$ organic waste collectors, $S C$ street cleaners, $A l l_{\text {field }}$ subjects submitted to field measurement with portable spiroergometric system

Founded significant differences between ${ }^{\mathrm{a}}$ male/female; ${ }^{\mathrm{b}} \mathrm{RWC} / \mathrm{SC} ;{ }^{\mathrm{c}} \mathrm{OWC} / \mathrm{SC},{ }^{\mathrm{d}} \mathrm{OWC}_{\text {field }} /$ all $\mathrm{field}_{\text {, }}$, and ${ }^{\mathrm{e}} \mathrm{SC}_{\text {field }} /$ all $_{\text {field }}$. The first four differences can be explained by the inclusion of women in the SC group, the latter not 
Spirometry represents a measure of forced one-second capacity and vital capacity $\left(\mathrm{FEV}_{1}, \mathrm{FVC}\right)$ performed according to the criteria of the American Thoracic Society (1995) with the calculation of $\mathrm{FEV}_{1} / \mathrm{FVC}$. In addition, body plethysmography determines the airways resistance as well as intrathoracic gas volume.

CPX was performed according to the recommendations of the German Society of Pneumology (Meyer et al. 2013) with 12-lead ECG monitoring on an electronically braked computer-controlled cycle ergometer (ergoselect 200p/ Ergoline Bitz, Germany) with a continuous increase in the load. This ramp-like protocol enables a precise determination of maximal aerobic and power output and the ventilatory threshold (VT) (Binder et al. 2008; Meyer et al. 2005). Performance and $\mathrm{VO}_{2}$ and carbon dioxide outputs $\left(\mathrm{VCO}_{2}\right)$ were measured continuously (Oxycon Pro ${ }^{\mathrm{TM}}$ by JAEGER $^{\mathrm{TM}} /$ CareFusion, Hoechberg, Germany).

CPX was preceded by 2 min of sitting at rest. After a warm-up period of 2 min with an external workload of $25 \mathrm{~W}$, the exercise followed with an increase of $15-25 \mathrm{~W} /$ min (Meyer et al. 2013) depending on the individual fitness level. Subjects were verbally encouraged until they could no longer sustain the required crank frequency of $60-70 \mathrm{rpm}$. Maximum oxygen uptake $\left(\mathrm{VO}_{2}\right.$, max $)$ was calculated as the average of the highest eight consecutive breaths in the final minute of exercise. The standard equations by Hansen et al. (1984), Reiterer (1975), and Wasserman et al. (2004) for $\mathrm{VO}_{2, \max }$ and maximal wattage $\left(P_{\max }\right)$ were used for assessment. The VT corresponds to the first VT; it was determined with a combination of $\mathrm{VCO}_{2} / \mathrm{VO}_{2}$ slope and increase in minute ventilation (VE) relative to oxygen consumption ( $\left.\mathrm{VE} / \mathrm{VO}_{2}\right)$, ventilatory equivalent named. This first VT is defined by the increase in $\mathrm{VE} / \mathrm{VO}_{2}$ without a concurrent increase in VE/ $/ \mathrm{VCO}_{2}$ (Binder et al. 2008; Westhoff et al. 2013).

Forty-one subjects were studied while working with long-term HR measurements (T31 coded transmitter, Polar Electro, Buettelborn, Germany) during a work shift (mean 6.7 h). From this group, 20 subjects (18 males and 2 females) were also connected to mobile CPX (Oxycon Mobile by JAEGER ${ }^{\mathrm{TM}} /$ CareFusion, Hoechberg, Germany) and to the HR monitoring system for an average of $1.3 \mathrm{~h}$ to measure the correlation between HR and oxygen uptake under field conditions $\left(\mathrm{HR}_{\text {field }}, \mathrm{VO}_{2 \text {,field }}\right)$ (Fig. 1). The field measurement was started before the truck left the depot and thus recorded approximately $30 \mathrm{~min}$ of driving plus $1 \mathrm{~h}$ of sustained work. The actual HR and oxygen uptake under task-specific work were recorded during the following $1 \mathrm{~h}$ of continuous work $\left(\mathrm{HR}_{1 \mathrm{~h}}, \mathrm{VO}_{2,1 \mathrm{~h}}\right)$. Part of the work of the garbage collectors is transporting two-wheeled waste containers (120 l volume) of houses and cellars and the shift of large four-wheeled waste containers (240 1) of storerooms. The path length of an entire work day was estimated with

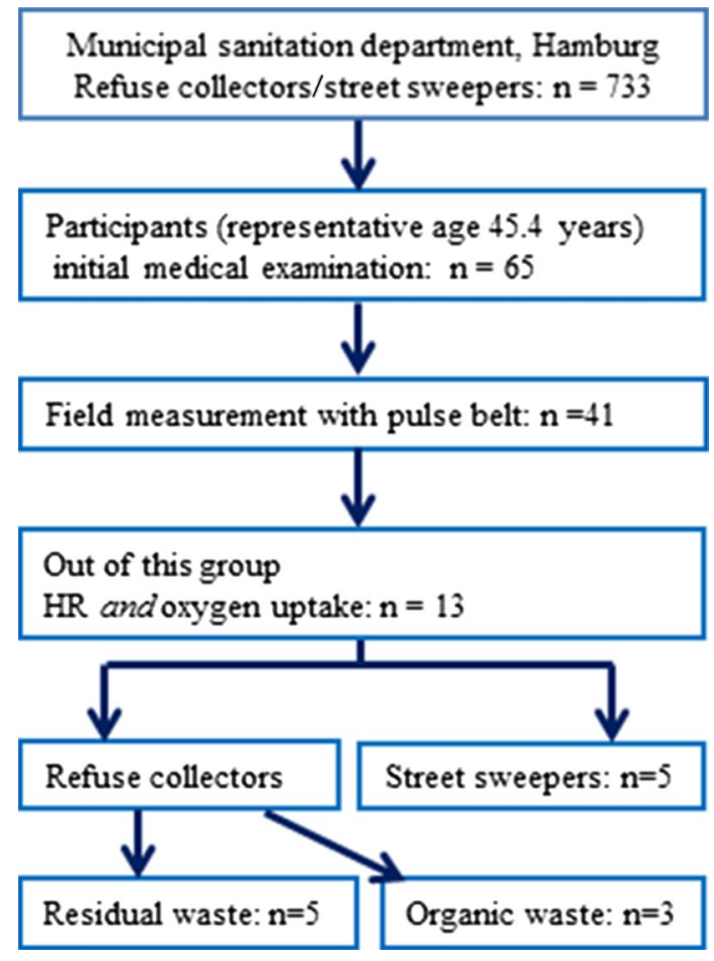

Fig. 1 Flowchart of the measurements

a pedometer and was about $7-10 \mathrm{~km}$. All waste containers were emptied machine-supported into the truck (Fig. 2a, b, photographs with waste worker, spiroergo mask, and garbage cans). Occasional waste bags were towed. SC consisted of sweeping waste and leaves, sometimes wet leaves, as well as picking up trash. Due to malfunction of the measuring instruments, refusal, and changes in the organization, valid data were obtained for only 13 of 20 subjects.

Ahead of the gas exchange measurements in the field via face mask, the mobile CPX unit was volume and gas calibrated. HR and oxygen uptake were both depicted in absolute values and relative to individuals' maximum values $\left(\% \mathrm{HR}_{\max }, \% \mathrm{VO}_{2, \max }\right)$ and individuals' values at the VT $\left(\% \mathrm{HR}_{\mathrm{VT}}, \% \mathrm{VO}_{2, \mathrm{VT}}\right)$. The difference to maximum values as "reserve values" $\left(\% \mathrm{HR}_{\mathrm{R}}, \% \mathrm{VO}_{2, \mathrm{R}}\right)$ was defined as: $\left(\mathrm{HR}_{\text {work }}-\mathrm{HR}_{\text {rest }}\right) /\left(\mathrm{HR}_{\text {max }}-\mathrm{HR}_{\text {rest }}\right) \times 100 \%$, and $\left(\mathrm{VO}_{2 \text {,work }}-\mathrm{VO}_{2, \text { rest }}\right) /\left(\mathrm{VO}_{2, \text { max }}-\mathrm{VO}_{2 \text {,rest }}\right) \times 100 \%$, respectively. The $\mathrm{HR}$ and $\mathrm{VO}_{2}$ at rest $\left(\mathrm{HR}_{\mathrm{rest}}, \mathrm{VO}_{2 \text {,rest }}\right)$ were calculated from the mean values in the first 2 min of the exercise test and the previously measured resting value.

\section{Statistics}

Data are presented as means and standard deviations (SD). To assess the equivalence of linear regression, mean values for Pearson correlation $(R)$, intercept, and slope were 

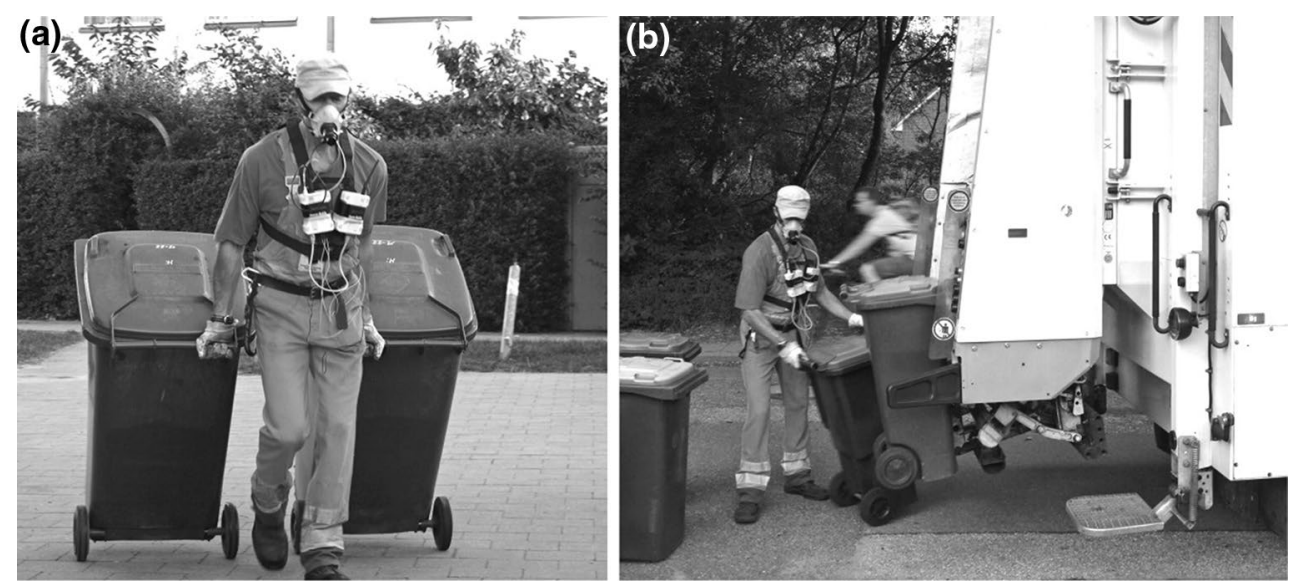

Fig. 2 a, b Refuse collector with spiroergo mask, equipment, and garbage cans

Table 2 Mean heart rate during a work shift $\left(\mathrm{HR}_{\mathrm{sh}}\right)$ of $6.7 \mathrm{~h}$ of $n=41$, percentage of maximal heart rate $\left(\% \mathrm{HR}_{\max }\right)$, and heart rate at the ventilatory threshold $\left(\% \mathrm{HR}_{\mathrm{VT}}\right)$ from CPX (values relative to heart rate reserve $\left(\% \mathrm{HR}_{\mathrm{R}}\right)$ )

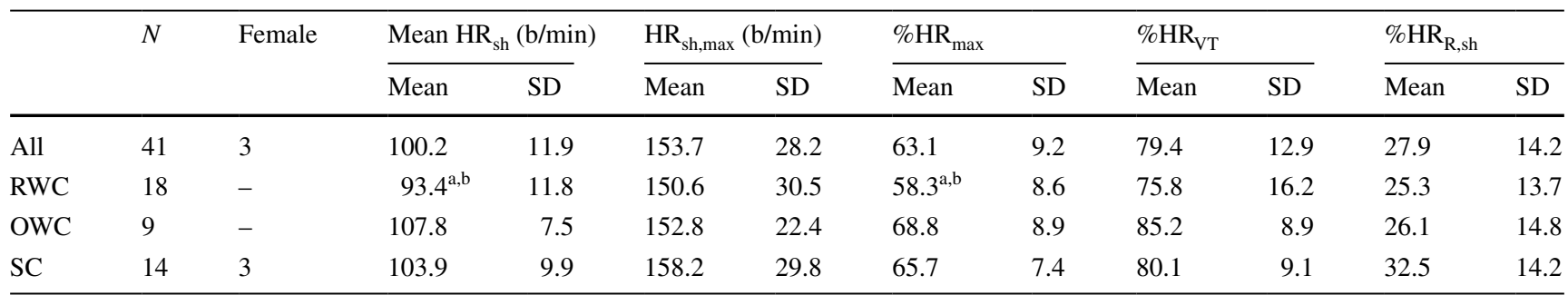

$R W C$ Residual waste collectors, $O W C$ organic waste collectors, $S C$ street cleaners

a Significant difference RWC/OWC

b Significant difference RWC/SC

determined for each individual. Student's $t$ test and Wilcoxon test were used to determine whether the mean intercepts and slopes differed from 0 to 1 , respectively, and to verify differences between sample characteristics and differences from reference limits. All calculations were performed using IBM SPSS Statistics 22. For all statistical analyses, the null hypothesis was rejected at a probability of $p<0.05$.

\section{Results}

The 65 subjects of the study group showed only low differences in age and in body mass within the total sample for RWC, OWC, and SC, respectively (Table 1). All 61 subjects who could participate in the CPX had normal ECG readings and took no HR-affecting drugs. On the basis of spirometry and body plethysmography, obstructive lung disease $\left(\mathrm{FEV}_{1} /\right.$ FVC $<70 \%$ ) was observed in $21.5 \%$ of subjects. All workers diagnosed with pulmonary disorders were active or former smokers (35.4 and $43.1 \%$ of total sample, respectively).

The results from HR measurement at work $\left(\mathrm{HR}_{\mathrm{sh}}\right)$ of 41 subjects with an average work shift time of $6.7 \mathrm{~h}$ are shown in Table 2. Mean values of the total sample were $100.2 \mathrm{~b} /$ min and $27.9 \% \mathrm{HR}_{\mathrm{R}}$, respectively. The $\mathrm{HR}_{\mathrm{sh}}$ values relative to individuals' $\mathrm{HR}_{\max }$ and to $\mathrm{HR}_{\mathrm{VT}}\left(\% \mathrm{HR}_{\max }, \% \mathrm{HR}_{\mathrm{VT}}\right)$ determined in the laboratory CPX showed that the OWC had the highest strain compared with the three subgroups (data not shown in detail).

HR recorded during one representative work hour (Table 3) showed a slightly higher mean $\mathrm{HR}_{1 \mathrm{~h}}$ of $109.2 \mathrm{~b} /$ min and $45.1 \% \mathrm{HR}_{\mathrm{R}}$, respectively, for the 13 subjects (for whom also the oxygen uptake was measured) than in the measurement over the whole work shift of the total sample. There were no significant differences between the groups OWC, RWC, and SC for $1 \mathrm{~h}$ of measurement. Mean HR values during $1 \mathrm{~h}$ as well as during a work shift were close to the HR at VT. Between $\mathrm{HR}_{1 \mathrm{~h}}$ and $\mathrm{HR}_{\mathrm{sh}}$ of these 13 subjects, there was a mean correlation coefficient of $R$ 0.64 . The regression of $\mathrm{HR}_{1 \mathrm{~h}}$ was slightly but significantly $(p<0.05)$ higher than $\mathrm{HR}_{\mathrm{sh}}$ by $10.6 \mathrm{~b} / \mathrm{min}$. During the one representative working hour (Table 3), the group mean achieved an oxygen uptake $\left(\mathrm{VO}_{2,1 \mathrm{~h}}\right)$ of $1103 \mathrm{ml} / \mathrm{min}$. Here too, mean $\mathrm{VO}_{2}$ was close to $\mathrm{VO}_{2, \mathrm{VT}}$. The groups did not differ significantly. 
Table 3 Average of heart rate $\left(\mathrm{HR}_{1 \mathrm{~h}}\right)$ and oxygen uptake $\left(\mathrm{VO}_{2,1 \mathrm{~h}}\right)$ during $1 \mathrm{~h}$ of work

\begin{tabular}{|c|c|c|c|c|c|c|c|c|c|c|c|c|c|c|c|}
\hline & \multirow[t]{2}{*}{$N$} & \multicolumn{2}{|c|}{$\mathrm{HR}_{1 \mathrm{~h}}(\mathrm{~b} / \mathrm{min})$} & \multicolumn{2}{|c|}{$\% \mathrm{HR}_{\mathrm{R}, 1 \mathrm{~h}}$} & \multicolumn{2}{|c|}{$\% \mathrm{HR}_{\max }$} & \multicolumn{2}{|c|}{$\% \mathrm{HR}_{\mathrm{VT}}$} & \multicolumn{2}{|c|}{$\mathrm{VO}_{2,1 \mathrm{~h}}(\mathrm{ml})$} & \multicolumn{2}{|c|}{$\% \mathrm{VO}_{2, \max }$} & \multicolumn{2}{|c|}{$\% \mathrm{VO}_{2, \mathrm{VT}}$} \\
\hline & & Mean & SD & Mean & SD & Mean & SD & Mean & SD & Mean & SD & Mean & SD & Mean & SD \\
\hline All field & 13 & 109.2 & 12.5 & 45.1 & 18.9 & 71.1 & 11.5 & 86.7 & 17.2 & 1103 & 237.3 & 45.7 & 9.3 & 60.0 & 14.3 \\
\hline $\mathrm{RWC}_{\text {field }}$ & 5 & 106.4 & 15.0 & 38.3 & 20.3 & 66.6 & 9.8 & 84.5 & 22.1 & 1160 & 137.0 & 42.9 & 5.8 & 57.8 & 15.1 \\
\hline OWC $_{\text {field }}$ & 3 & 106.5 & 9.1 & 32.7 & 12.7 & 67.2 & 13.5 & 82.4 & 14.3 & 1286 & 80.2 & 50.8 & 7.2 & 69.1 & 13.3 \\
\hline $\mathrm{SC}_{\text {field }}^{\mathrm{a}}$ & 5 & 113.7 & 12.7 & 59.3 & 12.6 & 78.0 & 10.7 & 91.6 & 15.8 & 935 & 287.1 & 45.2 & 13.0 & 56.7 & 14.5 \\
\hline
\end{tabular}

$\mathrm{HR}_{1 \mathrm{~h}}$ and $\mathrm{VO}_{2, \mathrm{hh}}$ relative to maximal heart rate and maximal oxygen uptake during $\mathrm{CPX}\left(\% \mathrm{HR}_{\max } ; \% \mathrm{VO}_{2, \max }\right) . \mathrm{HR}_{1 \mathrm{~h}}$ and $\mathrm{VO}_{2, \mathrm{~h}}$ relative to heart rate and oxygen uptake at the ventilatory threshold $\left(\% \mathrm{HR}_{\mathrm{VT}} ; \% \mathrm{VO}_{2}, \mathrm{VT}\right)$. And values relative to heart rate reserve $\left(\% \mathrm{HR}_{\mathrm{R}}\right)$

$R W C$ Residual waste collection, $O W C$ organic waste collection, $S C$ street cleaning, $A l_{\text {field }}$ subjects submitted to field measurement with portable spiroergometric system

Table 4 Results of CPX tests

\begin{tabular}{|c|c|c|c|c|c|c|c|c|c|c|c|c|c|c|}
\hline & \multirow[t]{2}{*}{$N$} & \multirow[t]{2}{*}{ Female } & \multicolumn{2}{|l|}{$\begin{array}{l}P_{\max } \\
(\mathrm{W})\end{array}$} & \multicolumn{2}{|c|}{$\begin{array}{l}P_{\max } \\
(\mathrm{W} / \mathrm{kg})\end{array}$} & \multicolumn{2}{|c|}{$\begin{array}{l}\mathrm{VO}_{2, \text { max }} \\
(\mathrm{ml})\end{array}$} & \multicolumn{2}{|c|}{$\begin{array}{l}\mathrm{VO}_{2, \max } \\
(\mathrm{ml} / \mathrm{kg})\end{array}$} & \multicolumn{2}{|c|}{$\begin{array}{l}\mathrm{HR}_{\max } \\
\text { (b/min) }\end{array}$} & \multicolumn{2}{|c|}{$\mathrm{RER}_{\text {max }}$} \\
\hline & & & Mean & SD & Mean & SD & Mean & SD & Mean & SD & Mean & SD & Mean & SD \\
\hline All & $61^{\mathrm{a}}$ & 3 & 192.1 & 39.2 & 2.1 & 0.5 & 2623 & 571 & 29.2 & 6.4 & 158.9 & 14.3 & 1.27 & 0.12 \\
\hline $\mathrm{All}_{\text {field }}$ & 13 & 2 & 184.5 & 46.9 & 2.1 & 0.5 & 2458 & 562 & 28.4 & 5.5 & 155.2 & 14.1 & 1.26 & 0.13 \\
\hline $\mathrm{RWC}_{\text {field }}$ & 5 & - & 200.0 & 17.0 & 2.3 & 0.2 & 2739 & 398 & 31.0 & 2.2 & 160.0 & 4.8 & 1.25 & 0.15 \\
\hline $\mathrm{OWC}_{\text {field }}$ & 3 & - & 180.0 & 56.3 & 1.8 & 0.6 & 2562 & 372 & 25.2 & 4.6 & 162.0 & 27.2 & 1.22 & 0.28 \\
\hline $\mathrm{SC}_{\text {field }}$ & 5 & 2 & 171.6 & 64.8 & 2.2 & 0.7 & 2113 & 682 & 27.7 & 7.8 & 146.2 & 6.4 & 1.28 & 0.06 \\
\hline
\end{tabular}

a The difference to Table 1 can be explained by the exclusion of four people due to cardiac disease or medication

Table 5 Heart rate $\left(\mathrm{HR}_{\mathrm{VT}}\right)$, power output $\left(P_{\mathrm{VT}}\right)$, and oxygen uptake $\left(\mathrm{VO}_{2, \mathrm{VT}}\right)$ at ventilatory threshold $(\mathrm{VT})$ from CPX tests [relative to maximal values from $\left.\mathrm{CPX}\left(\% P_{\max }, \% \mathrm{VO}_{2, \max }, \% \mathrm{HR}_{\max }\right)\right]$

\begin{tabular}{|c|c|c|c|c|c|c|c|c|c|c|c|c|c|c|}
\hline & \multirow[t]{2}{*}{$N$} & \multirow[t]{2}{*}{ Female } & \multicolumn{2}{|c|}{$P$ at $\mathrm{VT}(\mathrm{W})$} & \multicolumn{2}{|c|}{$\mathrm{VO}_{2}$ at $\mathrm{VT}(\mathrm{ml})$} & \multicolumn{2}{|c|}{$\mathrm{HR}$ at VT (b/min) } & \multicolumn{2}{|l|}{$\% P_{\max }$} & \multicolumn{2}{|c|}{$\% \mathrm{VO}_{2, \max }$} & \multicolumn{2}{|c|}{$\% \mathrm{HR}_{\max }$} \\
\hline & & & Mean & SD & Mean & SD & Mean & SD & Mean & SD & Mean & SD & Mean & SD \\
\hline All & 61 & 3 & 129.7 & 43.6 & 1843 & 498 & 125.1 & 15.3 & 66.9 & 16.3 & 70.3 & 11.8 & 79.0 & 9.3 \\
\hline $\mathrm{All}_{\text {field }}$ & 13 & 2 & 130.0 & 49.5 & 1914 & 549 & 128.4 & 15.8 & 69.2 & 12.6 & 77.1 & 8.0 & 82.9 & 8.4 \\
\hline $\mathrm{RWC}_{\text {field }}$ & 5 & - & 143.0 & 43.1 & 2109 & 514 & 129.6 & 20.1 & 70.5 & 17.0 & 76.0 & 9.3 & 81.0 & 12.7 \\
\hline $\mathrm{OWC}_{\text {field }}$ & 3 & - & 115.0 & 43.6 & 1908 & 400 & 131.3 & 19.3 & 63.1 & 4.4 & 74.0 & 4.5 & 81.3 & 2.4 \\
\hline $\mathrm{SC}_{\text {field }}$ & 5 & 2 & 126.0 & 64.5 & 1723 & 684 & 125.4 & 11.7 & 71.6 & 12.0 & 80.0 & 8.6 & 85.7 & 5.9 \\
\hline
\end{tabular}

$R W C$ Residual waste collectors, $O W C$ organic waste collectors, $S C$ street cleaners, $A l_{\text {field }}$ subjects submitted to field measurement with portable spiroergometric system

The results of CPX with measurement of $\mathrm{VO}_{2}$ of all 61 participants and of the 13 subjects with field measured data are depicted in Tables 4 and 5. The three subgroups RWC, OWC, and SC do not differ significantly in this test with respect to $P_{\max }, \mathrm{VO}_{2, \max }$, and $\mathrm{HR}_{\text {max }}$ (data not shown). The spiroergometric field measurements' sample of 13 subjects did not differ significantly from the whole group. A relationship between the maximal values from $P_{\max }$ and $\mathrm{VO}_{2, \max }$ could be observed with mean correlation coefficient $(R)$ of $0.88 ; \mathrm{HR}_{\max }$ was weakly correlated with age $(R$ $0.45)$. Therefore, older participants showed surprisingly a slight increase in $\mathrm{HR}_{\max }$ with age (data not shown in detail). The individuals reached values close to age-predicted values with $95.6 \%$ (SD 18.2) $\mathrm{VO}_{2, \max } / \mathrm{VO}_{2, \text { pred }}$, and $90.8 \%$ (SD 7.4) $\mathrm{HR}_{\max } / \mathrm{HR}_{\text {pred }}$, (Hansen et al. 1984; Reiterer 1975; Wasserman et al. 2004).

The linear regression analysis was accomplished to study the relationship between $\mathrm{HR}$ and $\mathrm{VO}_{2}$ for $\mathrm{CPX}$ and field measurement. Data of HR and oxygen uptake during CPX create an individual linear heart/oxygen uptake relationship and a substantial correlation (mean $R 0.89, p<0.001$ ). There was also a linear regression, with a mean correlation coefficient of 

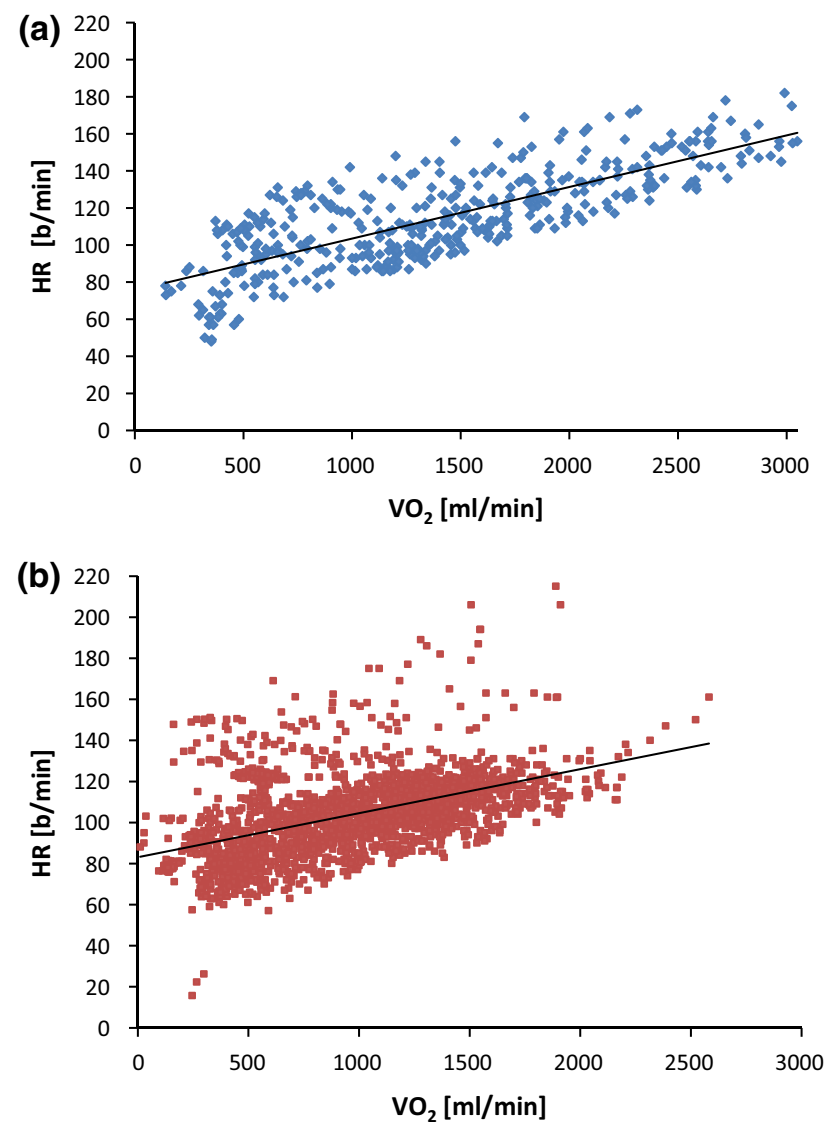

Fig. 3 Heart rate $(\mathrm{HR})$ and oxygen uptake $\left(\mathrm{VO}_{2}\right)$ during $\mathrm{CPX}$ with increasing workload by $15-25 \mathrm{~W} / \mathrm{min}$ (a) and during spiroergometric field measurement at work (b), for 13 subjects. a HR (b/ $\min )=0.03 \times \mathrm{VO}_{2}(\mathrm{ml} / \mathrm{min})+70.95($ drawn trendline $) ; R^{2}=0.80 ;$ $n=426 ; p<0.001$. b. HR $(\mathrm{b} / \mathrm{min})=0.03 \times \mathrm{VO}_{2}(\mathrm{ml} / \mathrm{min})+76.2$ (drawn trendline) $R^{2}=0.65 ; n=2191 ; p<0.001$

$R 0.78(p<0.001)$ between $\mathrm{HR}_{\text {field }}$ and $\mathrm{VO}_{2, \text { field }}$. The equations obtained here were nearly the same; both regressions for CPX and field measurement are shown in Fig. 3a, b. The correlation between $\% \mathrm{HR}_{\mathrm{R}}$ and $\% \mathrm{VO}_{2, \mathrm{R}}$ during $\mathrm{CPX}$ was high $(R 0.96)$. The correlation during field measurement was similar, albeit lower, $(R 0.78$, both $p<0.001)$ (Fig. $4 \mathrm{a}, \mathrm{b})$.

During the field measurement of continuous $\mathrm{HR}_{\text {field }}$ and

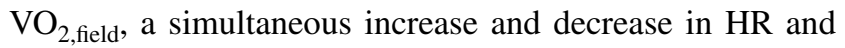
oxygen uptake could be observed in each individual. In Fig. 5, a typical example is given of one subject.

\section{Discussion}

\section{Relationship of $\mathrm{HR}$ to $\mathrm{VO}_{2}$ to determine the validity of measuring methods in the field}

Heart rate increases linearly as a function of workload intensity and is closely related to oxygen uptake (Arts and
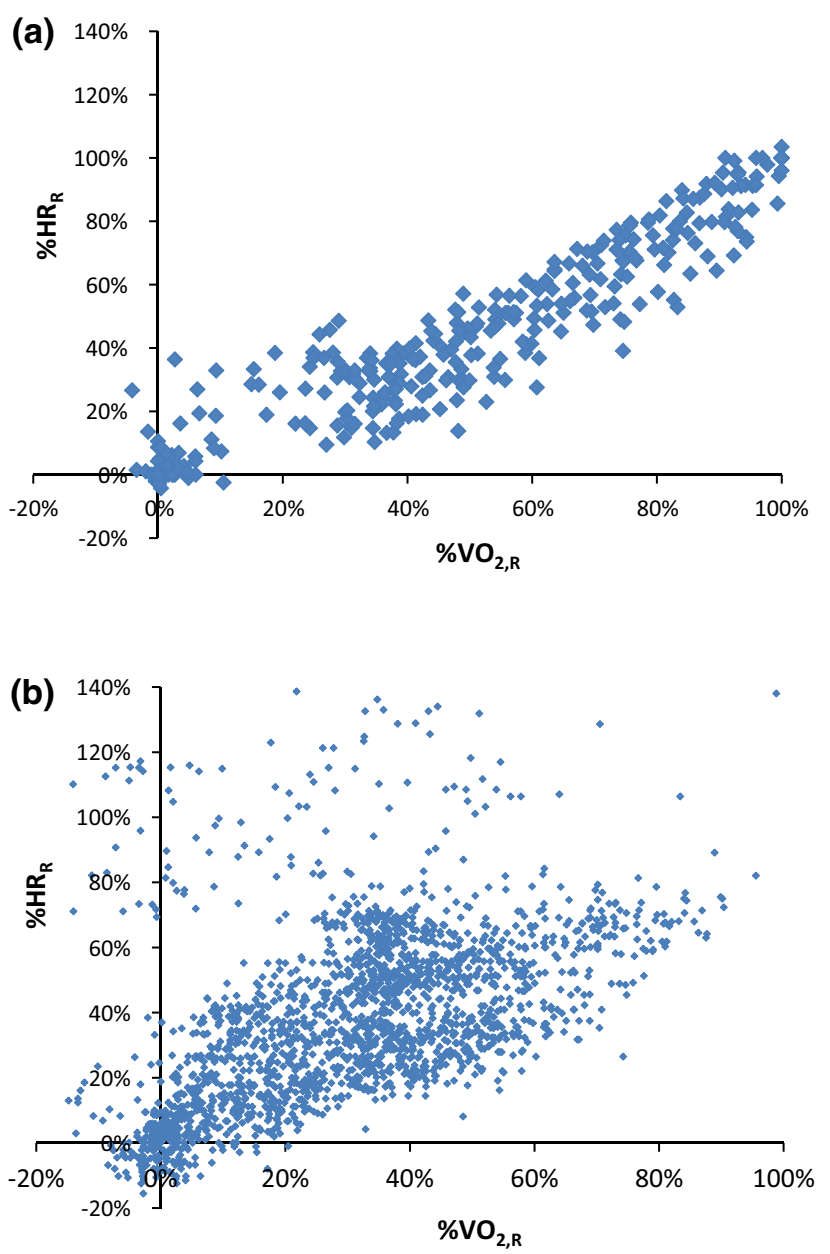

Fig. 4 Heart rate as a percentage of heart rate reserve $\left(\% \mathrm{HR}_{\mathrm{R}}\right)$ in relation to oxygen uptake as a percentage of oxygen uptake reserve $\left(\% \mathrm{VO}_{2, \mathrm{R}}\right)$, determined during $\mathrm{CPX}(\mathbf{a})$ and field measurement (b), for 13 subjects. a $\% \mathrm{HR}_{\mathrm{R}}=0.925 \times \% \mathrm{VO}_{2, \mathrm{R}}(\mathrm{ml} / \mathrm{min})-0.017$; $R^{2}=0.93 ; n=325 ; p<0.001 . \mathbf{b} \% \mathrm{HR}_{\mathrm{R}}=0.783 \times \% \mathrm{VO}_{2, \mathrm{R}}(\mathrm{ml} /$ $\min )+0.130 ; R^{2}=0.68 ; n=2146 ; p<0.001$

Kuipers 1994; Gastinger et al. 2010). Nevertheless, the value of the $\mathrm{HR} / \mathrm{VO}_{2}$ relationship can vary between individuals due to metabolic stress or physical training level and therefore should be ascertained individually (Skinner et al. 2003). Similarly, interindividual differences are observed when CPX and field measurements during work are compared. To determine the physiological workload of physically demanding work, we investigated the relation between HR and oxygen uptake under field conditions. We could demonstrate that the $\mathrm{HR} / \mathrm{VO}_{2}$ relationship was linear not just during the incremental cycle exercise test (CPX) but also in their usual working environment with climatic and other factors. Nevertheless, the range of the correlation coefficients shows that HR is more strongly correlated to $\mathrm{VO}_{2}$ during CPX $(R 0.89, p<0.001)$ than during field measurement $(R 0.78, p<0.001)$ (Fig. 3a, b). Yet, there is 
Fig. 5 Case report: heart rate and oxygen uptake during field measurement $\left(\mathrm{HR}_{\text {field }}, \mathrm{VO}_{2 \text {,field }}\right)$ of one subject. Individual maximal heart rate, maximal oxygen uptake $\left(\mathrm{HR}_{\max }, \mathrm{VO}_{2, \max }\right)$, and the values at ventilatory threshold $\left(\mathrm{HR}_{\mathrm{VT}}, \mathrm{VO}_{2, \mathrm{VT}}\right)$ are also shown

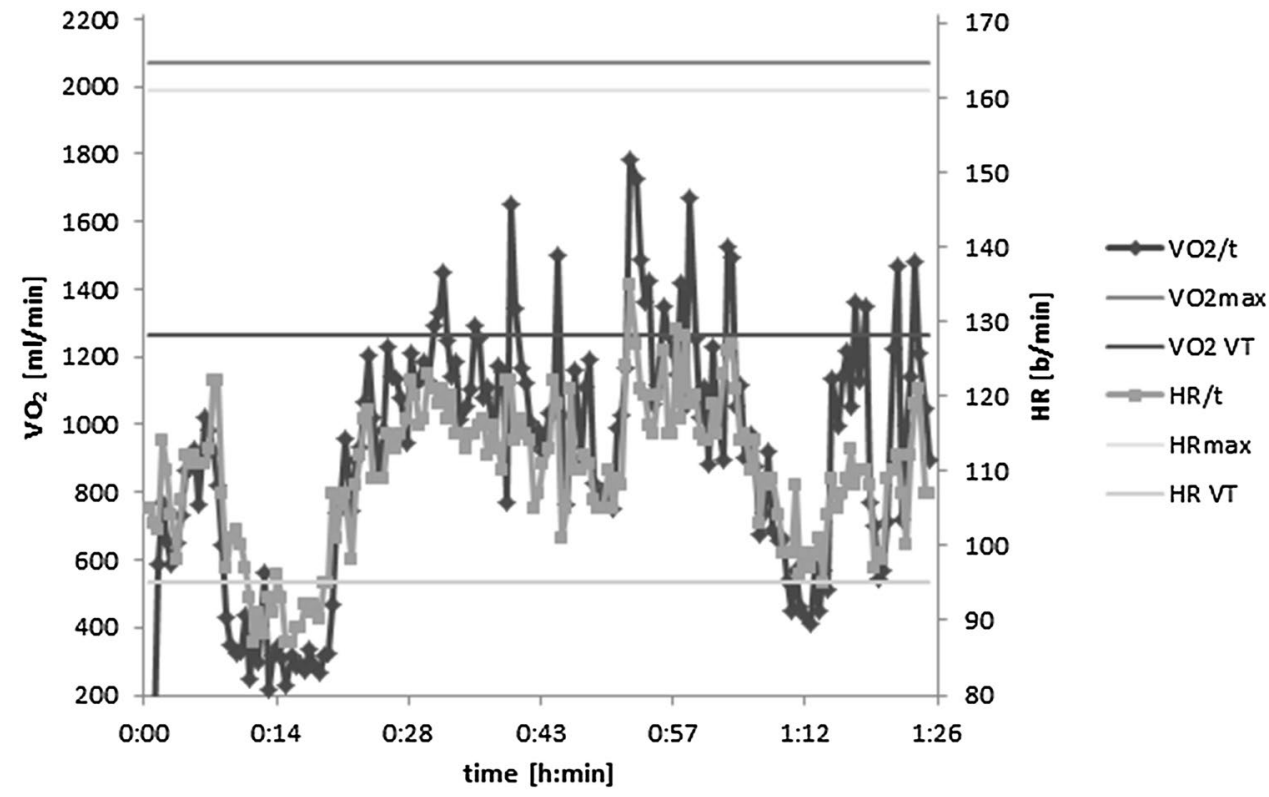

a significant correlation between $\mathrm{HR}$ and $\mathrm{VO}_{2}$ in the field measurement, and furthermore, a congruent increasing and decreasing profile could be demonstrated (Fig. 5).

Due to different proportions between $\mathrm{HR}$ and $\mathrm{VO}_{2}$, a method based on heart rate reserve $\left(\% \mathrm{HR}_{\mathrm{R}}\right)$ and $\mathrm{VO}_{2}$ reserve $\left(\% \mathrm{VO}_{2, \mathrm{R}}\right)$ is widely used for the comparison of relative values. Swain and Leutholtz (1997) and recent studies by Lounana et al. (2007) have shown that $\% \mathrm{HR}_{\mathrm{R}}$ data at group level are consistent with $\% \mathrm{VO}_{2, \mathrm{R}}$. We aimed to find out whether this correlation can also be validated for our group in CPX and especially in spiroergometric field measurement under working conditions. For the incremental exercise testing, we can confirm a substantial correlation of $\% \mathrm{HR}_{\mathrm{R}}$ and $\% \mathrm{VO}_{2, \mathrm{R}}$ with $R 0.96$ ( $\left.p<0.01\right)$ (Fig. 4a). For spiroergometric field measurement, we found a lower correlation of $R 0.78(p<0.001)$. Both regressions show that $\% \mathrm{HR}_{\mathrm{R}}$ does not overestimate $\% \mathrm{VO}_{2, \mathrm{R}}$ as their intercepts are close to 0 (Fig. 4b). Possible reasons for lower field correlations between $\mathrm{HR}$ and $\mathrm{VO}_{2}$ could be malfunctioning in gathering the individual values, different load shapes, and the varyingly high intensity of physical strain of muscle groups with differing efficiency. During work as a refuse collector, especially arm work is performed, while the incremental cycle exercise consists mostly of legwork. A better equivalence between $\% \mathrm{HR}_{\mathrm{R}}$ and $\% \mathrm{VO}_{2, \mathrm{R}}$ for legwork than for arm work has been described by (Rotstein and Meckel 2000). Additionally, HR can be impaired by further factors, such as temperature, emotion, and physical fitness status (Achten and Jeukendrup 2003). We nevertheless could demonstrate an equivalence between absolute values of $\mathrm{HR}$ and $\mathrm{VO}_{2}$, and equally in relative calculations to $\mathrm{HR}_{\mathrm{R}}$ and $\mathrm{VO}_{2, \mathrm{R}}$ in dynamic work, even if it was measured in the field.

\section{Fitness and workload capacity evaluated by various thresholds and aspects}

Because the VT reflects the workload threshold beyond which endurance exercise will not lead to anaerobic metabolism, it can therefore be regarded as the upper limit of intensity during the endurance performance (Binder et al. 2008). The present study showed a high endurance performance for the entire sample during $1 \mathrm{~h}$ of work and also during the whole work shift, depending on the HR measurement with a mean of $86.7 \% \mathrm{HR}_{\mathrm{VT}}$ and $79.4 \%$ $\mathrm{HR}_{\mathrm{VT}}$, respectively. The percentage of $\mathrm{VO}_{2}$ during $1 \mathrm{~h}$ of work in percentage of $\mathrm{VO}_{2, \mathrm{VT}}$ was likewise, but lower, with a mean of $60 \% \mathrm{VO}_{2, \mathrm{VT}}$. In Fig. 5, which shows a representative measurement from the field tests, the subject's $\mathrm{HR}$ well exceeded most of the time the individual $\mathrm{HR}_{\mathrm{VT}}$. Similarly, $\mathrm{VO}_{2, \mathrm{VT}}$ was exceeded several times. For individual values relative to the VT $\left(\% \mathrm{HR}_{\mathrm{VT}}, \% \mathrm{VO}_{2, \mathrm{VT}}\right)$, our data show that $\% \mathrm{HR}_{\mathrm{VT}}$ may overestimate the real workload; $\% \mathrm{VO}_{2, \mathrm{VT}}$ seems to be more realistic (see Table 5). Furthermore, VT not only differs between individuals but also varies depending on the state of training and the type of exercise protocol (Faude et al. 2009). Therefore, the question arises whether $\% \mathrm{HR}_{\mathrm{VT}}$ is comparable to $\% \mathrm{VO}_{2, \mathrm{VT}}$. We would recommend to determine VT and likewise the $\mathrm{HR}_{\mathrm{VT}}$ and $\mathrm{VO}_{2, \mathrm{VT}}$, by $\mathrm{CPX}$ in the laboratory. This will enable an accurate estimate of $\% \mathrm{VO}_{2, \mathrm{VT}}$ during the field measurement. 
In our sample, the CPX results are close to the individual predicted and age-dependent values (Table 2). Kroidl et al. (2014) have described the requirements for high, normal, and pathological endurance performance, based on values at VT $>80 \%$, around $60 \%$, and $<40 \%$ of maximal values, respectively. In comparison, our subjects also reached performance levels in the upper range of normal endurance (Table 2). In the present study, workers show normal ranges of individual fitness. Long work periods with a high level of physical activity did not lead to an increase in maximal oxygen uptake, and only slightly better endurance performance was observed in them. This seems to be compatible with results from previous studies which also investigated workers with heavy workload (Ilmarinen et al. 1991; Søgaard et al. 1996).

It is commonly suggested that $33-40 \%$ of the individual's $\mathrm{VO}_{2, \max }$ should be the capable workload for $8 \mathrm{~h}$ of physical work (Åstrand et al. 2003; Ilmarinen 1992). But $\% \mathrm{VO}_{2, \max }$ depends on the type of exercise performed. According to Kemper et al. (1990), the acceptable limit for refuse collecting work in particular, which mainly consists of arm work combined with legwork, should be at $30 \%$ $\mathrm{VO}_{2 \text {,max }}$ for an 8-h shift. To describe the exercise intensity in our sample, we took $\mathrm{HR}_{\mathrm{sh}}$ at a given $\% \mathrm{VO}_{2, \max }$. This method is according to Skinner et al. (2003); they have demonstrated that once $\mathrm{VO}_{2, \max }$ and the relationship among $\mathrm{HR}$ and $\mathrm{VO}_{2}$ are known, the corresponding $\mathrm{HR}$ is a good estimate for relative workload. Taking the mean HR values of the 41 subjects in our study who had undergone $\mathrm{HR}_{\mathrm{sh}}$ measurement, there was a slight exceedance (mean HR $100.2 \mathrm{~b} / \mathrm{min}$ ) of the standards of calculated mean HR value at $30 \% \mathrm{VO}_{2, \max }(96.6 \mathrm{~b} / \mathrm{min})$; $\left.\mathrm{ns}\right)$. Here, $66 \%$ of the individuals had mean $\mathrm{HR}_{\mathrm{sh}}$ values above $30 \% \mathrm{VO}_{2 \max }$. FringsDresen and Kemper 1995, under laboratory conditions, showed that 33-59\% of the subjects, depending on the waste collector activity (bags, different container volumes), exceeded the $30 \%$ of $\mathrm{VO} 2$ max.

Comparing these results with the oxygen uptake of the 13 individuals from the 1-h $\mathrm{VO}_{2}$ measurement, the means even exceeded the reference of $30 \% \mathrm{VO}_{2 \text {,max }}$ significantly (mean $\mathrm{VO}_{2,1 \mathrm{~h}} 1103 \mathrm{ml} / \mathrm{min}$ vs. calculated $\mathrm{VO}_{2}$ at $30 \%$ $\mathrm{VO}_{2, \text { max }}$ of $737.3 \mathrm{ml} / \mathrm{min}, p<0.05$ ). All subjects achieved a mean $\mathrm{VO}_{2}$, which was above the reference limit of $30 \%$ $\mathrm{VO}_{2, \max }$, with a total range of 35-69\% $\mathrm{VO}_{2, \max }$. These results are consistent with the relation between $\mathrm{HR}_{1 \mathrm{~h}}$ and $\mathrm{HR}_{\mathrm{sh}}$ as the 1-h values were slightly but significantly higher than $\mathrm{HR}_{\mathrm{sh}}$. Nevertheless, in both specifications (HR and $\mathrm{VO}_{2}$ ), very high values have been found, which reflects the high continuous work load of refuse collectors.

In general, exercises that are performed with a $\mathrm{HR}_{\mathrm{R}}>30 \%$ for an 8-h shift are assumed to be at high cardiovascular load (Ilmarinen et al. 1991; Shimaoka et al. 1998). With long-term HR measurement for a work shift of
$6.7 \mathrm{~h}, 39 \%$ of residual waste collectors, $33 \%$ of organic waste collectors, and $39 \%$ of the street cleaners had $\% \mathrm{HR}_{\mathrm{R}, \mathrm{sh}}$ values that were higher than $30 \% \mathrm{HR}_{\mathrm{R}}$. These findings are consistent with Kuijer et al. (1999), who found $36.4 \% \mathrm{HR}_{\mathrm{R}}$ for refuse collectors and $22.6 \% \mathrm{HR}_{\mathrm{R}}$ for street sweepers. Therefore, we can conclude that refuse collectors and street cleaners have high endurance performance and high cardiovascular load during work.

Åstrand et al. (2003) specified easy, moderate, and heavy work during an 8-h work shift on the basis of oxygen consumption at $<600,600-1000$, and $>1000 \mathrm{ml} / \mathrm{min}$ $\mathrm{VO}_{2}$, respectively, and required a maximum $\mathrm{VO}_{2}$ for work at $40 \% \mathrm{VO}_{2, \text { max }}$ at $<1500,<1500-2500$, and $>2500 \mathrm{ml} /$ min, respectively. When compared to Åstrand's requirements of workload, the refuse collectors in our study had a mean $\mathrm{VO}_{2,1 \mathrm{~h}}$ of $1103 \mathrm{ml} / \mathrm{min}$ during work corresponding to $46 \% \mathrm{VO}_{2, \text { max }}$ (Table 4) and a mean $\mathrm{VO}_{2, \max }$ of $2623 \mathrm{ml} / \mathrm{min}$ during CPX corresponding to oxygen uptake under heavy physical work. This confirms Åstrand's findings; the workload of refuse collectors can be classified in the upper field of heavy work. Whether the relatively high physical endurance is a health risk for the refuse collectors remains open. In our initial cross-sectional study, we found no evidence to this.

\section{Comparison with other occupations}

Compared to jobs which are commonly referred to as physically heavy, the relative workload found in this study was rather high. The means for $\mathrm{HR}_{\mathrm{sh}}$ and $\% \mathrm{HR}_{\max }$ (Table 3) during one work shift are consistent with Wultsch et al. (2012) findings for workers from waste processing (activities were not differentiated). They found mean $\mathrm{HR}_{\mathrm{sh}} 100 \mathrm{~b} /$ min for male and 120 for female, 59 and $65 \% \mathrm{HR}_{\max }$, respectively. Compared to the other investigated professions (workers in metal industry, slaughterhouse work, or healthcare business) referred in this study (Wultsch et al. 2012), our findings on the physical demand of refuse collectors were higher. Compared to a study with housekeepers which also used a portable spiroergometric system for field measurements (MJ Fröhlich, personal communication), we found similar values at $\mathrm{HR}_{1 \mathrm{~h}}$ and $\mathrm{VO}_{2,1 \mathrm{~h}}$ to those they determined with $112 \mathrm{~b} / \mathrm{min}$ and $1.06 \mathrm{l} / \mathrm{min}$, respectively. However, compared to portable spiroergometric measurements with lumberjacks (Hagen et al. 1993) - their job is considered to be the hardest form of physical work (with $49 \% \mathrm{VO}_{2, \max }$ for the younger, $53 \% \mathrm{VO}_{2, \max }$ for the older, and a $\mathrm{HR}_{\mathrm{sh}}$ of 138 and $126 \mathrm{~b} / \mathrm{min}$, respectively) —our measurement results were rather low.

Other studies with refuse collectors have also reported similar HR values to those found in our study. Kemper et al. (1990) have found a mean $\mathrm{HR}_{\mathrm{sh}}$ of $99.5 \mathrm{~b} / \mathrm{min}$ in Dutch refuse collectors during one work shift, and-compared to 
the threshold value of $30 \% \mathrm{VO}_{2, \max }$ calculated over $\mathrm{HR}_{\mathrm{sh}}$ $30 \%$ of their participants had exceeded that limit. Furthermore, they also established a linear relationship between $\mathrm{HR}$ and $\mathrm{VO}_{2}$ during work, but they did not describe this correlation further. In a recent study with Brazilian refuse collectors, Anjos et al. (2007) outlined a mean HR for the total working time at $97.6 \mathrm{~b} / \mathrm{min}, 53.4 \% \mathrm{HR}_{\max }$, and $32.8 \% \mathrm{HR}_{\mathrm{R}}$; nevertheless, their results were partially lower than those found in the present study. In addition, they identified HR values during the actual working time which can be compared with our values for $1 \mathrm{~h}$ of continuous work. A recent Japanese study by Tsujimura et al. (2012) found mean HR values for garbage collectors of $97.5 \mathrm{~b} /$ min, which were similar to the Brazilians but lower than our findings. These studies of refuse collectors, however, determined the workload only by the $\mathrm{HR}$ without $\mathrm{VO}_{2}$ field measurements.

\section{Conclusion}

The present study demonstrates that HR and oxygen consumption are strongly correlated even during field measurements of the heavy dynamic work of the refuse collectors. Therefore, HR measurement is a valuable tool for evaluating the parameters of physiological workload during work. But the correlation between $\mathrm{HR}$ and $\mathrm{VO}_{2}$ was stronger under steady conditions in the laboratory, while HR can also be influenced by several external circumstances. In addition, we included only persons without heart disease or medication. In persons with cardiac disease or HR influencing medication, the sole determination of HR cannot replace the measurement of $\mathrm{VO}_{2}$. Therefore, if possible, the determination of $\mathrm{VO}_{2}$ should be aimed in the field measurement.

Refuse collectors exceed the upper limits set for physical work stress in the literature (Åstrand et al. 2003; Ilmarinen et al. 1991; Shimaoka et al. 1998). But all investigated employees were in our study within their individual reference limits of physical capacity and aerobic fitness, both in terms of absolute and relative HR as well as in oxygen consumption. The three task-specific groups (RWC, OWC, SC) did not differ in workload. The results of the present study can finally confirm the high workload of refuse collectors with the determination of $\mathrm{VO}_{2}$ at work. In addition, the endurance workload of refuse collectors is well above the hitherto recommended limits. The currently applicable limits for an 8-h shift with a maximum of 33-40\% of the individual's $\mathrm{VO}_{2 \text { max }}$ or $\mathrm{HR}_{\mathrm{R}}>30 \%$ should be reviewed. Other field measurements with determination of oxygen uptake with other physically hardworking professionals are necessary.

Acknowledgments The authors would like to thank L. Herrmann, Stadtreinigung, Hamburg, for his support in recruiting the volunteers, and H.-J. Krankenhagen and A. Frosch for preparing heart rate data in the field measurements. We would like to thank Sabine Bößler and Anne Winkelmann for their excellent support with the technical patient examinations. We are indebted to Cordula Bittner, MD, and Thomas von Münster, MD, who implemented clinical examinations. The study is a part of the investigation: "Ergonomic study of waste collectors in the system garbage collection and street cleaning of the municipal sanitation department in Hamburg" and was funded by a grant from Stadtreinigung, Hamburg.

Conflict of interest The authors declare that they have no conflict of interest.

Ethical standard All procedures performed in studies involving human participants were in accordance with the ethical standards of the institutional and/or national research committee and with the Declaration of Helsinki 1964 and its later amendments or comparable ethical standards.

Open Access This article is distributed under the terms of the Creative Commons Attribution 4.0 International License (http://creativecommons.org/licenses/by/4.0/), which permits unrestricted use, distribution, and reproduction in any medium, provided you give appropriate credit to the original author(s) and the source, provide a link to the Creative Commons license, and indicate if changes were made.

\section{References}

Achten J, Jeukendrup AE (2003) Heart rate monitoring: applications and limitations. Sports Med 33(7):517-538

American Thoracic Society (1995) Standardization of spirometry. Am J Respir Crit Care Med 152:1107-1136

Anjos LA, Ferreira JA, Damiao JJ (2007) Heart rate and energy expenditure during garbage collection in Rio de Janeiro, Brazil. Cad Saude Publica 23(11):2749-2755

Arts FJ, Kuipers H (1994) The relation between power output, oxygen uptake and heart rate in male athletes. Int J Sports Med 15(5):228-231

Åstrand PO, Rodahl K, Dahl HA, Stromme SB (2003) Textbook of work physiology: physiological bases of exercise, 4th edn. Human Kinetics Publishers, Champaign, II

Binder RK, Wonisch M, Corra U, Cohen-Solal A, Vanhees L, Saner H, Schmid JP (2008) Methodological approach to the first and second lactate threshold in incremental cardiopulmonary exercise testing. Eur J Cardiovasc Prev Rehabil 15(6):726-734

Faude O, Kindermann W, Meyer T (2009) Lactate threshold concepts: how valid are they? Sports Med 39(6):469-490

Frings-Dresen MHW, Kemper HCG, Stassen ARA, Crolla IFAM, Markslag AMT (1995) The daily workload of refuse collectors working with three different collecting methods: a field study. Ergonomics 38:2045-2055

Gastinger S, Sorel A, Nicolas G, Gratas-Delamarche A, Prioux J (2010) A comparison between ventilation and heart rate as indicator of oxygen uptake during different intensities of exercise. $\mathrm{J}$ Sports Sci Med 9(1):110-118

Hagen KB, Vik T, Myhr NE, Opsahl PA, Harms-Ringdahl K (1993) Physical workload, perceived exertion, and output of cut wood as related to age in motor-manual cutting. Ergonomics 36(5):479-488

Hansen JE, Sue DY, Wasserman K (1984) Predicted values for clinical exercise testing. Am Rev Respir Dis 129(2 Pt 2):S49-S55 
Ilmarinen J (1992) Job design for the aged with regard to the decline in their maximal aerobic capacity: part I D guidelines for the practitioner. Int J Ind Ergon 10:53-63

Ilmarinen J, Louhevaara V, Korhonen O, Nygard CH, Hakola T, Suvanto S (1991) Changes in maximal cardiorespiratory capacity among aging municipal employees. Scand J Work Environ Health 17(Suppl 1):99-109

Kemper HC, van Aalst R, Leegwater A, Maas S, Knibbe JJ (1990) The physical and physiological workload of refuse collectors. Ergonomics 33(12):1471-1486

Kroidl RF, Schwarz S, Lehnigk B, Fritsch J (2014) Kursbuch Spiroergometrie, 3rd edn. Thieme, Stuttgart

Kuijer PP, Frings-Dresen MH (2004) World at work: refuse collectors. Occup Environ Med 61(3):282-286

Kuijer PP, Visser B, Kemper HC (1999) Job rotation as a factor in reducing physical workload at a refuse collecting department. Ergonomics 42(9):1167-1178

Kuijer PP, Sluiter JK, Frings-Dresen MH (2010) Health and safety in waste collection: towards evidence-based worker health surveillance. Am J Ind Med 53(10):1040-1064

Lounana J, Campion F, Noakes TD, Medelli J (2007) Relationship between \%HRmax, \%HR reserve, \% VO2max, and \% VO2 reserve in elite cyclists. Med Sci Sports Exerc 39(2):350-357

Meyer T, Lucia A, Earnest CP, Kindermann W (2005) A conceptual framework for performance diagnosis and training prescription from submaximal gas exchange parameters-theory and application. Int J Sports Med 26(Suppl 1):S38-S48

Meyer FJ, Borst MM, Buschmann HC, Ewert R, Friedmann-Bette B, Ochmann U, Petermann W, Preisser AM, Rohde D, Ruhle KH, Sorichter S, Stahler G, Westhoff M, Worth H (2013) Exercise testing in respiratory medicine. Pneumologie 67(1):16-34

Reiterer W (1975) Methodik eines rektangulären-triangulären Belastungstestes. Herz/Kreisl 7(9):457-462

Rotstein A, Meckel Y (2000) Estimation of \%VO2 reserve from heart rate during arm exercise and running. Eur J Appl Physiol 83(6):545-550
Rutenfranz J, Hettinger T, Ilmarinen J, Klimmer F (1976) Beurteilung der Eignung zu schwerer körperlicher Arbeit. In: Drasche H, Essing HG, Florian HJ et al (eds) Ökologischer Kurs: Teil Arbeitsmedizin. Ferdinand Enke, Stuttgart, pp 12-24

Shimaoka M, Hiruta S, Ono Y, Nonaka H, Hjelm EW, Hagberg M (1998) A comparative study of physical work load in Japanese and Swedish nursery school teachers. Eur J Appl Physiol Occup Physiol 77(1-2):10-18

Skinner JS, Gaskill SE, Rankinen T, Leon AS, Rao DC, Wilmore $\mathrm{JH}$, Bouchard C (2003) Heart rate versus \%VO2max: age, sex, race, initial fitness, and training response: HERITAGE. Med Sci Sports Exerc 35(11):1908-1913

Søgaard K, Fallentin N, Nielsen J (1996) Work load during floor cleaning: the effect of cleaning methods and work technique. Eur J Appl Physiol Occup Physiol 73(1-2):73-81

Swain DP, Leutholtz BC (1997) Heart rate reserve is equivalent to \%VO2 reserve, not to \%VO2max. Med Sci Sports Exerc 29(3):410-414

Tsujimura H, Taoda K, Kitahara T (2012) A field study on the physiological workload of garbage collectors in the Japanese summer. Ind Health 50(6):556-566

Wasserman K, Hansen JE, Sue DY, Stringer WW, Whipp BJ (2004) Principles of exercise testing and interpretation, 4th edn. Lippincott Raven, Baltimore

Westhoff M, Ruhle KH, Greiwing A, Schomaker R, Eschenbacher H, Siepmann M, Lehnigk B (2013) Positional paper of the German working group "cardiopulmonary exercise testing" to ventilatory and metabolic (lactate) thresholds. Dtsch Med Wochenschr 138(6):275-280

Wultsch G, Rinnerhofer S, Tschakert G, Hofmann P (2012) Governmental regulations for early retirement by means of energy expenditure cut offs. Scand J Work Environ Health 38(4):370-379 